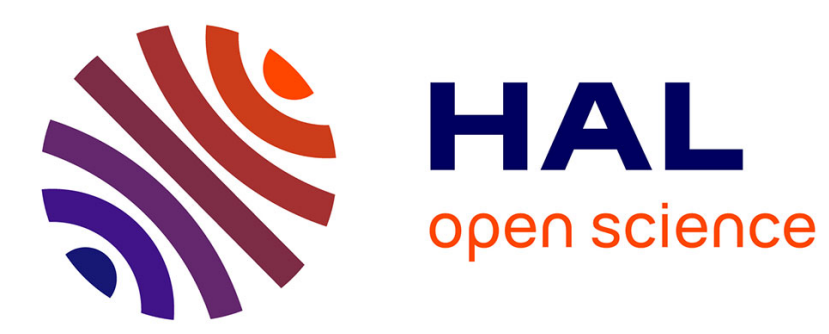

\title{
From Neuroeconomics to Genetics: The Intertemporal Choices Case as an Example
}

Sacha Bourgeois-Gironde, Itzhak Gingi Aharon

\section{To cite this version:}

Sacha Bourgeois-Gironde, Itzhak Gingi Aharon. From Neuroeconomics to Genetics: The Intertemporal Choices Case as an Example. Richard Ebstein Simone Shamay-Tsoory Soo Hong Chew. From DNA to Social Cognition, Wiley and Blackwell, pp.233-244, 2011, 14. ijn_00713466

\section{HAL Id: ijn_00713466 \\ https://hal.science/ijn_00713466}

Submitted on 1 Jul 2012

HAL is a multi-disciplinary open access archive for the deposit and dissemination of scientific research documents, whether they are published or not. The documents may come from teaching and research institutions in France or abroad, or from public or private research centers.
L'archive ouverte pluridisciplinaire HAL, est destinée au dépôt et à la diffusion de documents scientifiques de niveau recherche, publiés ou non, émanant des établissements d'enseignement et de recherche français ou étrangers, des laboratoires publics ou privés. 


\section{AUTHOR QUERY FORM}

Dear Author,

During the preparation of your manuscript for publication, the questions listed below have arisen. Please attend to these matters and return this form with your proof.

Many thanks for your assistance.

\begin{tabular}{|c|c|c|}
\hline $\begin{array}{l}\text { Query } \\
\text { References }\end{array}$ & Query & Remarks \\
\hline 1 & $\begin{array}{l}\text { AU: fMRI was remove as it is mentioned in } \\
\text { previous paragraph, These are other modalities }\end{array}$ & \\
\hline 2 & $\begin{array}{l}\text { AU: Ref Breiter was not found on Ref List. } \\
\text { Please add to list or remove from text. }\end{array}$ & \\
\hline 3 & AU: Please provide a page number for the quote. & \\
\hline 4 & $\begin{array}{l}\text { AU: Ref Hariri was not found on ref list, Please } \\
\text { add to list or remove text. }\end{array}$ & \\
\hline 5 & AU: Please provide page \# for quote & \\
\hline 6 & $\begin{array}{l}\text { AU: Ref Chabris } 2007 \text { was not found on Ref list. } \\
\text { Please add to list or remove from text. }\end{array}$ & \\
\hline 7 & $\begin{array}{l}\text { AU: Are these direct quotes? If so, Please } \\
\text { provide Page \#. }\end{array}$ & \\
\hline 8 & $\begin{array}{l}\text { AU: All Refs without a } \checkmark \text { was not found cited in } \\
\text { text. Please add to reference list or remove from } \\
\text { reference list. }\end{array}$ & \\
\hline 9 & AU: Please provide pg \#. & \\
\hline 10 & $\begin{array}{l}\text { AU: Ref was not found cited in text. Please add } \\
\text { to reference list or remove from reference list. }\end{array}$ & \\
\hline 11 & AU: Please provide pg \#. & \\
\hline 12 & $\begin{array}{l}\text { AU: Ref was not found cited in text. Please add } \\
\text { to reference list or remove from reference list. }\end{array}$ & \\
\hline 13 & $\begin{array}{l}\text { AU: Ref was not found cited in text. Please add } \\
\text { to reference list or remove from reference list. }\end{array}$ & \\
\hline
\end{tabular}




\begin{tabular}{|l|l|l|}
\hline $\begin{array}{l}\text { Query } \\
\text { References }\end{array}$ & Query & Remarks \\
\hline 14 & $\begin{array}{l}\text { AU: Ref was not found cited in text. Please add } \\
\text { to reference list or remove from reference list. }\end{array}$ & \\
\hline 15 & $\begin{array}{l}\text { AU: Ref was not found cited in text. Please add } \\
\text { to reference list or remove from reference list. }\end{array}$ & \\
\hline 16 & AU: Please provide page \#. & \\
\hline 17 & $\begin{array}{l}\text { AU: Ref was not found cited in text. Please add } \\
\text { to reference list or remove from reference list. }\end{array}$ & \\
\hline 18 & $\begin{array}{l}\text { AU: Fisher (1930) has not been found in the list. } \\
\text { Please provide full reference details or delete } \\
\text { from the text. }\end{array}$ & \\
\hline
\end{tabular}




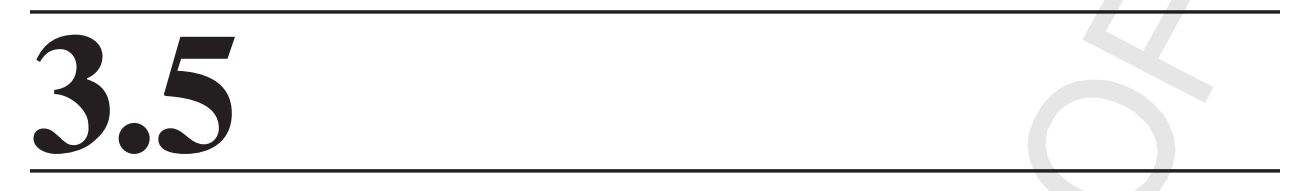

\title{
FROM NEUROECONOMICS TO GENETICS: THE INTERTEMPORAL CHOICES CASE AS AN EXAMPLE
}

\author{
ITZHAK AHARON $^{1}$ AND SACHA BOURGEOIS-GIRONDE ${ }^{2}$ \\ ${ }^{1}$ Interdisciplinary Centre, Herzliya, Israel \\ ${ }^{2}$ Institut Jean-Nicod (ENS-EHESS), Paris, France
}

Despite substantial advances, the question of how we make decisions and judgments continues to pose important challenges for scientific research. Historically, different disciplines have approached this problem using different techniques and assumptions, with few unifying efforts made (Sanfey, Loewenstein, McClure, \& Cohen, 2006). Previous behavioral and economic research has focused on stimulus input and behavioral output, often ignoring the intermediary steps by which information is processed and decisions are made.

There is now an extensive literature describing the many ways in which human decision making violates the principles of rationality as defined by the expected utility (EU) (Starmer, 2000) and discounted utility (DU) (Frederick et al., 2002) models (Sanfey et al., 2006). Early work in economics revealed situations (e.g., Ellsberg \& Allais paradoxes) whereby behavior violated key axioms of the EU model. More recently, the "heuristics and biases" approach in psychology has documented many instances of deviations from economic rationality (Kahneman et al., 1982). For example, most people are reluctant to take a gamble with $50 \%$ chance of winning $\$ 25$ and $50 \%$ chance of losing $\$ 20$, despite the gamble's overall positive expected value. This illustrates the phenomena of "loss aversion," whereby people often place disproportionate weight on losses relative to gains of similar absolute value (Kahneman et al., 1991).

From DNA to Social Cognition, First Edition. Richard Ebstein, Simone Shamay-Tsoory, Soo Hong Chew.

(C) 2012 Wiley-Blackwell. Published 2012 by John Wiley \& Sons, Inc. 


\subsubsection{WHAT IS NEUROECONOMICS}

A very recent approach, popularly known as neuroeconomics, has sought to integrate ideas from the fields of psychology, neuroscience, and economics in an effort to specify more accurate models. Brain imaging techniques such as functional magnetic resonance imaging (fMRI) or positron emission tomography (PET) can be used to determine areas of relative brain activation and to deduce the specific portions of the brain used, during decision-making tasks. Functional neuroimaging doing the past decade has provided a new way to examine brain behavior relationships (Mandzia \& Black, 2001).

As human beings, we live in an unpredictable and complex world. Yet, we have learned to adapt and to make choices that ensure our well-being. Evolution has endowed organisms with various mechanisms that ensure its behaviors maintain Darwinian fitness. Specifically, the brain's reward system encodes information about the value of the potential outcomes of our actions. This information is highly relevant to other cognitive brain systems because it motivates our actions and, in an abstract sense, adds purpose to our behavior.

Neuroeconomics research has identified a biological mechanism mediating behavior motivated by events commonly associated with pleasure in humans. These events are termed "rewards" and are viewed as primary factors governing normal behavior. The subjective impact of rewards (e.g., pleasure) can be considered essential (e.g., Young, 1959) or irrelevant (e.g., Skinner, 1953) to their effect on behavior, but the motivational effect of rewards on behavior is universally acknowledged by experimental psychologists.

Neuroeconomics provides an important scientific approach to the study of behavior because of the ability to improve understanding of the role of the human brain in decision making (Clithero, Tankersley, \& Huettel, 2008). Research in the field of neuroeconomics suggests a common neural currency (i.e., utility) in the judgment of various reward types as well as other factors that affect value (e.g., reward size,

\section{BOX 3.5-1 Neuroimaging}

Neuroimaging refers to the methodology that provides a visualization of the structure or function of elements of the nervous system. It includes the use of various techniques to image either directly or indirectly the structure and/or function/pharmacology of the nervous system. In addition to being used to diagnose disease and assess brain health, neuroimaging is also valuable in the study of brain dynamics, aiming to understand how the brain works and how various activities impact the brain. In a classic example of functional neuroimaging, fMRI can generate images in which different sections of the brain light up as they become active. Structural neuroimaging is static and concerned with the physical structure of the brain.

Other neuroimaging modalities include electroencephalography (EEG), magnetoencephalography (MEG), PET, or optical imaging. For review, please see R.J. Dolan (2008). 


\section{BOX 3.5-2 The Brain Reward System}

The brain reward system is a collection of brain structures that attempts to regulate and control behavior by inducing pleasurable effects. A psychological reward is a process that reinforces behavior. In neuroeconomics, reward and social interaction are central concepts to understand what motivates human behavior. Both concepts are investigated in humans using neuroimaging and physiological methods. For review, please see Schultz (2002).

\section{BOX 3.5-3 Criticizing Neuroeconomics}

Recently the use of neuroimaging techniques in research procedures has come under fire. According to one line of criticism, much of this use involves fundamental errors in data handling and statistics (Vul, Harris, Winkielman, \& Pashler, 2009). According to another line, much of it involves inappropriate experimental protocols that ignore basic features of the circuitry and functional organization of the brain (Logothetis, 2008).

Breiter et al., 2001; temporal delay to reward, McClure et al., 2004; Montague \& 2 Berns, 2002). Neuroeconomics also suggests that decision making is an emergent process that results from the interaction (synergistically or competitively) of independent neuronal subsystems (Sanfey et al., 2006). Among the topics that neuroeconomic methods may be best suited to examine, in combination with imaging techniques, is brain functioning in optimal and suboptimal decision making.

Clithero and his coauthors (2008) report that the neuroscience evidences that improves our understanding of economic phenomena (Camerer, Loewenstein, \& Prelec, 2005; Camerer 2007; Glimcher, 2003; Sanfey et al., 2006) come from a broad array of novel experimental findings, including demonstrations of brain regions that guide responses to fair (King-Casas et al., 2005; Singer et al., 2006) and unfair (Sanfey et al., 2003) social interactions, that resolve uncertainty during decision making (Yoshida \& Ishai, 2006), that track loss aversion (Tom, Fox, Trepel, \& Poldrack, 2007) and subjective value (Padoa-Schioppa \& Assad, 2006), and that encode willingness to pay (Knutson, Rick, Wirnmer, Prelec, \& Loewenstein, 2007; Plassmann, O'Doherty, \& Rangel, 2007) and reward error signals (Donchin, 2006). Yet, neuroeconomics has been characterized as a faddish juxtaposition, not integration, of disparate domains. In addition, critics have charged that neuroscience and economics are fundamentally incompatible (Gul \& Pesendorfer, 2008), an argument that resonates with many social scientists. Economics thrived for centuries in the absence of neuroscience, and some economists argue that existing neuroeconomics research is not useful to mainstream economics (Harrison, 2008).

Neuroeconomics is at a crossroads, poised to demonstrate that neuroscience can provide the same types of benefits it has long received from the social sciences (Clithero et al., 2008). Ideas from game theory and expected utility theory can 
explain the responses of individual neurons to incoming information (Glimcher, 2003). Similarly, aspects of utility theory can be used to describe the activity of populations of neurons within the brain's reward system (Schultz, 2006). There is also an opportunity for the axiomatic approach of decision theory to explain decision-making mechanisms, such as building from the response properties of dopaminergic neurons (Caplin \& Dean, 2008). Without comparable examples of neuroscience data contributing to economic models, critics could argue that neuroeconomics research is a brain-centric enterprise that incorporates ideas from the social sciences without reciprocation (Harrison, 2008).

Neuroeconomics draws attention to motive forces that are ignored in the standard framework of economic theory. For example, impulsivity and inconsistency in intertemporal choice have been attracting attention in economics. Although loss of self-control by substance abusers is strongly related to their inconsistency in intertemporal choice, researchers in economics have usually studied impulsivity in intertemporal choice using a discount rate (e.g., hyperbolic k), with little effort being expended on motive forces. In the rest of the chapter, we will describe and discuss intertemporal research from the neuroeconomics perspective.

\subsubsection{MODELING INTERTEMPRAL CHOICES}

When it comes to choice over time, there is also ample evidence of violations of the DU model. Perhaps most importantly, there is strong evidence that discounting is much steeper for shorter time delays than for longer delays, a phenomenon known as "hyperbolic time discounting" (Ainslie \& Haslam, 1992). For example, offered a choice between $\$ 10$ today and $\$ 11$ in a week, many people are likely to choose the immediate $\$ 10$. However, offered the choice between $\$ 10$ in a year and $\$ 11$ in a year and a week, most people would chose the $\$ 11$, now considering the extra week of wait inconsequential. From the economist's perspective, however, this implies a reversal of preference (i.e., whether an extra dollar is worth a week's wait) and, therefore, does not conform to the rational model (Frederick, Loewenstein, O'Donoghue, 2002).

The idea that the value of a good depends on the timing of its consumption was already present in the economic thought of the 18th century but discussed in more details by John Rae $(1834,1905)$ who is considered the "father" of intertemporal choices modeling. According to Rae, someone's time preferences are explained by his "effective desire of accumulation."

In 1884, Eugen von Böhm-Bawerk (1890) claimed that this systematic tendency to underestimate future pleasures may be attributed to humans lacking the capacity to make a complete picture of their future wants, especially when it comes to remotely distant ones. Fisher (1930) — who announced the basic economic relations in intertemporal choice-continued this approach, suggesting that every person has his own rate of "impatience," one that depends on objective factors (size and risk of future income) and subjective factors (foresight, strength of will, habit, uncertainty, selfishness, and influence of fashion). Paul Samuelson (1937) was the first economist who suggested the DU model, a mathematical function describing time preferences in general assuming that "the individual behaves so as to maximize the sum of all future utilities." 
Many economic decisions involve outcomes that occur at different points in time. To model such decisions, discounted utility models are typically used. These models combine a utility function that reflects attitudes toward outcomes and a discount function that captures the effect of the passage of time. The most widely used discounted utility model in economics is constant discounting in which the discount function is determined by a constant rate of discount. However, much empirical research has underlined "various inadequacies of the DU model as a descriptive model of behavior" which is a phenomenon referred to as decreasing impatience (Frederick et al., 2002; Read, 2001). One of the major anomalies is that discount rates seem not to be invariant over different horizons. Indeed, as noted by Strotz (1956), agents seem to discount the future relative to the present more rapidly than they discount between different dates in the future. According to this hypothesis, "people are impatient at present, but claim to be patient in the future" (Nir, 2004).

These findings have led to the development of alternative discounted utility models, which are commonly referred to as hyperbolic discounting. The hyperbolic discounting models are consistent with decreasing impatience and have become quickly popular in economics. Today many applications are based on hyperbolic discounting, in particular on quasi-hyperbolic discounting a model that was first proposed by Phelps and Pollak (1968) and made popular by Laibson (1997). In his work, Laibson (1997) suggested a discrete time discount function, the "quasihyperbolic," which captures the key property of hyperbolic discounting in a more tractable functional form: preferences at time $t$ are inconsistent with preferences at time $t+1$. Thus, a gap occurs between one's long-run goals and short-run behavior. This gap may elicit some type of behavior that should be invested by policy makers (for example, retirement issues and procrastination).

\subsubsection{NEUROECONOMICS AND INTERTEMPORAL CHOICES}

The tendency to choose lesser immediate benefits over greater long-term benefits characterizes alcoholism and other addictive disorders. However, despite its medical and socioeconomic importance, little is known about its neurobiological mechanisms. Brain regions that are activated when deciding between immediate or delayed rewards have been identified (McClure et al., 2004; McClure, Ericson, Laibson, Loewenstein, \& Cohen, 2007), as have areas in which responses to reward stimuli predict a paper-and-pencil measure of temporal discounting (Hariri et al., 2006). These studies assume "hot" and "cool" response selection systems, with the hot system proposed to generate impulsive choices in the presence of a proximate reward. However, to date, brain regions in which the magnitude of activity during decision making reliably predicts intertemporal choice behavior have not been identified (Boettiger et al., 2007).

Like humans, nonhuman animals can be run in experimental paradigms in which they choose between smaller earlier rewards and larger later rewards (although animals need to learn about the rewards through multiple trials, whereas humans can simply be informed of the contingencies). Monterosso and Ainslie (1999) note that "people and less cognitively sophisticated animals do not differ in the hyper- 5 bolic form of their discount curves." Some researchers (e.g., Herrnstein, 1997; Rachlin, 2000) hold the view that hyperbolic time discounting is effectively 
"hardwired" into our evolutionary apparatus. However, there is considerable evidence that the time discounting of humans and other animals relies on qualitatively different mechanisms (e.g., Loewenstein, 1996; Shefrin \& Thaler, 1988).

In support of this evidence, Rangel, Camerer, \& Montague, (2008) arguer that although both humans and animals discount the future at dramatically different rates, both humans and animals display a common pattern of time discounting commonly referred to as "hyperbolic time discounting." However, they believe that although such findings do not rule out the possibility that humans and animals discount the future similarly, the quantitative discontinuity is indicative of a qualitative discontinuity.

There is, in fact, considerable evidence that the time discounting of humans and other animals relies on qualitatively different mechanisms. Specifically, human time discounting reflects the operation of two fundamentally different systems, one that heavily values the present and cares little about the future (which we share with other animals), and another that discounts outcomes more consistently across time (which is uniquely human) (e.g., Loewenstein, 1996; Shefrin \& Thaler, 1988). Although (some) animals display far-sighted behaviors (e.g., storing nuts for winter), these are typically preprogrammed and distinct from the type of spontaneous selfcontrol observed in humans (e.g., deciding to go on a diet). The almost uniquely human capacity to take the delayed consequences of our behavior into account seems to be directly attributable to the prefrontal cortex, the part of the brain that was the most recent to expand in the evolutionary process that produced humans (Manuck, Flory, Muldoon, \& Ferrell, 2003), and that is also the latest part of the brain to develop with age. Patients with damage to prefrontal regions tend to behave myopically, placing little weight on the delayed consequences of their behavior (Damasio, Grabowski, Frank, Galaburda, \& Damasio, 1994).

Many different microfoundations have been proposed to explain the preference patterns captured by the hyperbolic and quasi-hyperbolic discount functions. The most prominent examples include temptation models and dual-brain neuroeconomic models (Bernheim \& Rangel, 2004; Gul \& Pesendorfer, 2001; McClure et al., 2004; Thaler \& Shefrin, 1981). However, both the properties and the mechanisms of time preferences remain in dispute.

For example, using fMRI, McClure et al. (2004) examined the brain activity of participants while they made a series of intertemporal choices between smaller proximal rewards $\left(\$ R\right.$ available at delay $d$ ) and larger delayed rewards $\left(\$ R^{\prime}\right.$ available at delay $d^{\prime}$ ), where $\$ R<\$ R^{\prime}$ and $d<d^{\prime}$. Rewards ranged from $\$ 5$ to $\$ 40$ Amazon.com gift certificates, and the delay ranged from the day of the experiment to 6 weeks later.

McClure et al. (2004) found that time discounting is associated with the engagement of two neural systems: Limbic and paralimbic cortical structures are preferentially recruited for choices involving immediately available rewards; and frontoparietal regions, which support higher cognitive functions, are recruited for all intertemporal choices. Moreover, the authors find that when choices involved an opportunity for immediate reward, thus engaging both systems, greater activity in frontoparietal regions than in limbic regions is associated with choosing larger delayed rewards. A subsequent fMRI study that replaced gift certificates with primary rewards (juice and water) that could be delivered instantly in the scanner replicated this pattern (McClure et al., 2007). Yet another study by a different set 
of authors (Hariri et al., 2006) found a similar pattern in a between- rather than within-subject study.

These studies seemed to support, at a neurobiological level, the dual-self $\beta-\delta$ model of David Laibson (1997), which was developed to explain the hyperbolic-like (quasi-hyperbolic) discounting behavior mentioned previously. However, contradictory to McClure studies $(2004,2007)$, Kable and Glimcher (2007) found no evidence of separable neural agents that could account for the multiple-selves theories.

Current knowledge regarding the neural basis of temporal discounting derives primarily from lesion studies (Boettiger et al., 2007). For example, damage to the human orbitofrontal cortex (OFC) (Berlin, Rolls, \& Kischka, 2004), but not to the ventromedial frontal lobe (Fellows \& Farah, 2005), increases immediate reward bias, whereas in rats, lesions of the OFC (Mobini et al., 2002; Rudebeck, Walton, Smyth, Bannerman, \& Rushworth, 2006), basolateral amygdala (Winstanley et al., 2004), nucleus accumbens (Cardinal, Pennicott, Sugathapala, Robbins, \& Everitt, 2001), or hippocampus (Cheung \& Cardinal, 2005) bias selection toward immediate rewards. Such selection bias may be viewed as a form of impulsivity (Evenden, 1999).

Correspondingly, polymorphisms (a genetic variant that appears in at least $1 \%$ of a population) in several genes in the dopaminergic system (related with the brain reward system and the previously mentioned brain regions) have been identified as likely contributors to impulsivity (Kreek, Nielsen, Butelman, \& LaForge, 2005).

Following the studies by McClure and his colleagues (McClure et al., 2004, 2007), Boettiger and his group (Boettiger et al., 2007) used fMRI and a modified delay discounting task (Mitchell, Fields, D'Esposito, Boettiger, 2005; Mitchell, Tavares, Fields, D'Esposito, Boettiger, 2007) to identify brain regions associated with immediate reward bias or anti-bias. To maximize the range of individual differences across subjects, participants were either abstinent alcoholics (AA; $n=9)$ or age-matched controls with no history of substance abuse $(\mathrm{CS} ; \mathrm{n}=10)$. In each trial of the task, subjects were instructed to choose between two amounts of money, a smaller amount available "Now" (e.g., "\$80 TODAY") or a larger amount available "Later" (e.g., "\$100 in 1 month"). The authors report that the tendency of an individual to wait for a larger, delayed reward correlates directly with the blood oxygenation leveldependent (BOLD) signal in the lateral orbitofrontal cortex. In addition, a genotype at the Val158Met polymorphism of the catechol-O-methyltransferase gene (an enzyme playing an important role in prefrontal cortex dopamine metabolism) predicts both impulsive choice behavior and activity levels in the prefrontal cortex during decision making.

\subsubsection{FUTURE RESEARCH SHOULD USE DISCOUNT RATES AS PHENOTYPES IN GENETIC STUDIES}

Different people are likely to have different discount rates (Chabris et al., 2009) as some people are more patient (low discount rate) and others are more impatient (high discount rate). Do individuals' discount rates help to explain their decisions about behaviors like saving, health, and smoking? This question was examined Christopher Chabris and his colleagues (Chabris et al., 2007).

The authors use a laboratory task to compute an individual-specific discount rate and then estimate the effect of the discount rate and demographic factors on 
behaviors such as saving and smoking. Although other studies have demonstrated a relationship between laboratory measures of discounting and various behaviors (Setlow, Mendez, Mitchell, \& Simon, 2009), this study is unique for its use of a large, diverse sample to examine a wide range of behaviors (15 in all) and to compare the predictive strength of the discount rate with that of demographic variables in explaining these behaviors.

The authors begin by estimating discount rates for more than 500 subjects using a laboratory task. The subjects engaged in three different substudies examining a large set of behaviors and health-related variables associated with making tradeoffs between the present and future.

Next the authors present a theoretical framework to explore how much of the variation in behavior we would expect discounting to explain.

The paper's results support two broad conclusions. First, "there exists a domaingeneral behavioral disposition towards impatience/impulsivity," and second, "a discount rate estimated through a set of intertemporal monetary choice questions constitutes a useful, though noisy, measure of this disposition." Therefore, the authors of the study (Chabris et al., 2007, 2009) suggest that future research could use discount rates as phenotypes in genetic studies design to indentify biological intertemporal choices mechanisms.

\subsubsection{OTHER FACTORS AFFECTING INDIVIDUAL'S TIME PREFERENCES}

Independently of subjects' discount rates, there are many other factors affecting individual's time preferences. Using data collected by questionnaires, Van der Pol and Cairns $(2000,2001)$ argue that younger people expect to have more responsibilities in the future. They are thus more likely to have negative discount rates. Older people are more likely to have positive discount rates because of their reduced life expectancy.

Another factor impacting on individual's time preferences is optimism (Berndsen \& van der Pligt, 2001). Uncertainty about the future allows for optimism (i.e., the hope that future losses will be avoided), and this optimism can underlie the preferences for present or future care. A study by Berndsen and van der Pligt (2001) found that people are willing to delay gains and to speed up losses. The authors suggest that optimism underlies the strong preference for immediate gains in both the monetary and the health domain. It is argued that optimism has asymmetric effects on time preferences for gains versus losses: One reason why decision makers prefer immediate gains is because they are optimistic that these gains will be followed by additional gains in future. In contrast, decision makers prefer to delay losses because they are optimistic that losses are avoidable in the future. Optimism about outcomes affects time preferences for both gains and losses, such that low optimism reduces the discount rates while increasing optimism.

In addition, many other factors affect time preferences, for example, people's assumptions regarding future technology in the field of health care. However, the evidence for correlation between these factors and the discount rate is weak and their individual effect on time preferences is hard to measure. 


\section{REFERENCES}

Ainslie, G., \& Haslam, N. (1992). Hyperbolic discounting. Choice Over Time, edited by G. Loewenstein and J. Elster, New York: Russell Sage.

Arnea, A., Cronqvist, H., \& Siegel, S. (2010). Nature or nurture: What determines investor behavior? J Financ Econ 98(3), 583-604.

Bernheim, D., \& Rangel, A. (2004). Addiction and cue-triggered decision processes. Am Econ Rev 94(5), 1558-1590.

Berlin, H. A., Rolls, E. T., \& Kischka, U. (2004). Impulsivity, time perception, emotion and reinforcement sensitivity in patients with orbitofrontal cortex lesions. Brain 127, 1108-1126.

Berndsen, M., \& van der Pligt, J. (2001). Time is on my side: Optimism in intertemporal choice. Acta Psychol 108(2), 173-186.

Boettiger, C. A., Mitchell, J. M., Tavares, V. C., Robertson, M., Joslyn, G., et al. (2007). Immediate reward bias in humans: Fronto-parietal networks and a role for the catecholO-methyltransferase 158(Val/Val) genotype. J Neurosci 7(52), 14383-14391.

Bohm-Bawerk, E.-von. (1890) [1884]. Capital and interest: A critical history of economical Theory. London: Macmillan.

Camerer, C., Loewenstein, G., \& Prelec, D. (2005). Neuroeconomics: How neuroscience can inform economics. J Econ Lit 43, 9-64.

Camerer, C. F. (2007). Neuroeconomics: Using neuroscience to make economic predictions. Econ J 117, C26-C42.

Caplin, A., \& Dean, M. (2008). Dopamine, reward prediction error, and economics. Quart J Econ 123, 663-701.

Cardinal, R. N., Pennicott, D. R., Sugathapala, C. L., Robbins, T. W., \& Everitt, B. J. (2001). Impulsive choice induced in rats by lesions of the nucleus accumbens core. Science 292, 2499-2501.

Chabris, C. F., Laibson, D., Morris, C. L., Schuldt, J. P., Taubinsky, D. (2009). The allocation of time in decision-making. $J$ Eur Econ Assoc 7(2), 628-637.

Cheung, T. H., Cardinal, R. N. (2005). Hippocampal lesions facilitate instrumental learning with delayed reinforcement but induce impulsive choice in rats. BMC Neurosci 6,36 .

Clithero, J. A., Tankersley, D., \& Huettel, S. A. (2008). Foundations of neuroeconomics: From philosophy to practice. PLoS Biol 6(11).

Damasio, H., Grabowski, T., Frank, R., Galaburda, A. M., \& Damasio, A. R. (1994). The return of Phineas Gage: Clues about the brain from the skull of a famous patient. Science 264(5162), 1102-1105.

Dehaene, S., \& Cohen, L. (2007). Cultural recycling of cortical maps. Neuron 56(2), 10 384-398.

Dolan, R. J. (2008). Neuroimaging of cognition: Past, present, and future. Neuron 60(3), 496-502.

Donchin, E. (2006). fMRI: Not the only way to look at the human brain in action. Observer 19.

Evenden, J. L. (1999). Varieties of impulsivity. Psychopharmacology 146, 348-361.

Fellows, L. K., Farah, M. J. (2005). Dissociable elements of human foresight: A role for the ventromedial frontal lobes in framing the future, but not in discounting future rewards. Neuropsychologia 43, 1214-1221. 
Frederick, S. et al. (2002). Time discounting and time preference: A critical review. J. Econ Lit 40, 351-401.

Frederick, S., Loewenstein, G., \& O’Donoghue, T. (2002). Time discounting and time preferences: A critical review. J Econ Lit 40(2), 351-401.

Glimcher, P. W. (2003). Decisions, Uncertainty, and the Brain: The Science of Neuroeconomics. Cambridge: MIT Press.

Gul, F. \& Pesendorfer, W. (2001). Temptation and self-control. Econometrica 69(6), 1403-1435.

Gul, F., \& Pesendorfer, W. (2008). The case for mindless economics. Foundations of Positive and Normative Economics, Methodologies of Modern Economics, edited by A. Caplin, \& A. Schotter. Oxford: Oxford University Press.

Harrison, G. W. (2008). Neuroeconomics: A critical reconsideration. Econ Philo 24, 303-344.

Herrnstein, R. J. (1997). The Matching Law: Papers in Psychology and Economics, edited by H. Rachlin \& D. Laibson. New York: Sage Publishers.

Jamison, J., \& Wegener, J. (2009). Multiple Selves in Intertemporal Choice. FRB Boston 12 Working Papers Series, Paper no. 09-17.

Kable, J. W., \& Glimcher, P. W. (2007). The neural correlates of subjective value during intertemporal choice. Nat Neurosci 10(12), 1625-1633.

Kahneman, D., et al. (1982). Judgment under uncertainty: Heuristics and biases. Cambridge, MA: Cambridge University Press.

Kahneman, D., et al. (1991). The endowment effect, loss aversion, and the status quo bias: Anomalies. J Econ Perspec 5, 193-206.

King-Casas, B., Tomlin, D., Anen, C., Camerer, C. F., Quartz, S. R., et al. (2005). Getting to know you: Reputation and trust in a two-person economic exchange. Science 308, 78-83.

Knutson, B., Rick, S., Wirnmer, G. E., Prelec, D., \& Loewenstein, G. (2007). Neural predictors of purchases. Neuron 53,147-156.

Kreek, M. J., Nielsen, D. A., Butelman, E. R., \& LaForge, K. S. (2005) Genetic influences on impulsivity, risk taking, stress responsivity and vulnerability to drug abuse and addiction. Nat Neurosci 8, 1450-1457.

Laibson, D. (1997). Golden eggs and hyperbolic discounting. Q J Econ 112(2), 443-477

Loewenstein, G. (1996). Out of control: Visceral influences on behaviour. Organ Behav and Hum Decis Process 65, 272-292.

Logothetis, N. K. (2008). What we can do and what we cannot do with fMRI? Nature 435, 869-878.

Mandzia, J., \& Black, S. E. (2001). Neuroimaging and behavior: Probing brain behavior relationships in the 21st century. Curr Neurol Neurosci Rep 1,553-561.

Mandzia, J., \& Black, S. E. (2007). Neuroimaging and behavior: Probing brain behavior relationships in the 21st century. Curr Neurol Neurosci Rep 1528-4042, 553-561.

Manuck, S. B., Flory, J. D., Muldoon, M. F., \& Ferrell, R. E. (2003). Central nervous system serotonergic responsivity and aggressive disposition in men. Physiol Behav 77(4-5), 705-709.

Mariëtte, B., \& Joop van der, P. (2001). Time is on my side: Optimism in intertemporal choice. 13 Acta Psychologica 108(2), 173-186.

McClure, S. M. et al. (2004). Separate neural systems value immediate and delayed monetary rewards. Science 306, 503-507.

McClure, S. M., Ericson, K. M., Laibson, D. I., Loewenstein, G., \& Cohen, J. D. (2007). Time discounting for primary rewards. J Neurosci 27(21), 5796-5804. 
Mitchell, J. M., Fields, H. L., D’Esposito, M., \& Boettiger, C. A. (2005). Impulsive responding in alcoholics. Alcohol Clin Exp Res 29, 2158-2169.

Mitchell, J. M., Tavares, V. C., Fields, H. L., D'Esposito, M., \& Boettiger, C. A. (2007). Endogenous opioid blockade and impulsive responding in alcoholics and healthy controls. Neuropsychopharmacology 32, 439-449.

Mobini, S., Body, S., Ho, M. Y., Bradshaw, C. M., Szabadi, E., et al. (2002). Effects of lesions of the orbitofrontal cortex on sensitivity to delayed and probabilistic reinforcement. Psychopharmacology 160, 290-298.

Montague, P. R., Berns, G. S. (2002). Neural economics and the biological substrates of valuation. Neuron 36, 265-284.

Monterosso, J. R., Ainslie, G. (1999). Beyond discounting: Possible experimental models of impulse control. Psychopharmacology 146, 339-347.

Nir, A. (2004), Cognitive Procedures and Hyperbolic Discounting, Tilburg University, Center for Economic Research, Discussion Paper No. 47.

Padoa-Schioppa, C., \& Assad, J. A. (2006). Neurons in the orbitofrontal cortex encode economic value. Nature 441, 223-226.

Phelps, E. S., \& Pollak, R. (1968), On second best national saving and game-equilibrium growth. Rev Econ Stud 35 185-199.

Plassmann, H., O'Doherty, J., \& Rangel, A. (2007). Orbitofrontal cortex encodes willingness to pay in everyday economic transactions. J Neurosci 27, 9984-9988.

Rae, J. (1905) [1834]. The Sociological Theory of Capital. London: Macmillan.

Rachlin, H. (2000). The Science of Self-Control Cambridge. London: Harvard University Press.

Rangel, A., Camerer, C., \& Montague, R. (2008). A framework for studying the neurobiology of value-based decision making. Nat Rev Neurosci 9, 545-556.

Read, D. (2001). Is time-discounting hyperbolic or subadditive? J Risk Uncertainty 23(1), 5-32.

Rudebeck, P. H., Walton, M. E., Smyth, A. N., Bannerman, D. M., \& Rushworth, M. F. (2006). Separate neural pathways process different decision costs. Nat Neurosci 9, 1161-1168.

Samuelson, P. (1937). A note on measurement of utility. Rev Econ Stud, 4, 155-161.

Sanfey, A. G., Loewenstein, G., McClure, S. M., \& Cohen, J. D. (2006). Neuroeconomics: Crosscurrents in research on decision-making. Trends Cogn Sci 10, 108-116.

Sanfey, A. G., Rilling, J. K., Aronson, J. A., Nystrom, L. E., \& Cohen, J. D. (2003). The neural 14 basis of economic decision-making in the ultimatum game. Science 300, 1755-1758.

Schultz, W. (2002). Getting formal with dopamine and reward. Neuron 36(2), 241-263.

Schultz, W. (2006). Behavioral theories and the neurophysiology of reward. Annu Rev Psychol 57, 87-115.

Setlow, B., Mendez, I. A., Mitchell, M. R., \& Simon, N. W. (2009). Effects of chronic administration of drugs of abuse on impulsive choice (delay discounting) in animal models. Behav Pharmacol 20(5-6), 380-389.

Shefrin, H. M., \& Thaler, R. H. 1988. The behavioral life-cycle hypothesis. Econ Inq 26(4), 609-643.

Singer, T., Seymour, B., O’Doherty, J. P., Stephan, K. E., Dolan, R. J., et al. (2006). Empathic neural responses are modulated by the perceived fairness of others. Nature 439 , 466-469.

Skinner, B. F. (1953). Science and Human Behavior. New York: Macmillan.

Starmer, C. (2000). Developments in non-expected utility theory: The hunt for a descriptive 15 theory of choice under risk. J Econ Lit 38, 332-382. 
Strotz, R. (1956). Myopia and inconsistency in dynamic utility maximization. Rev Econ Stud $23,165-180$.

Thaler, R. H., \& Shefrin, H. M. (1981). An economic theory of self-control. J Polit Econ 89 (2), 392-406.

Tom, S. M., Fox, C. R., Trepel, C., \& Poldrack, R. A. (2007). The neural basis of loss aversion in decision-making under risk. Science 315, 515-518.

Van der Pol, M., \& Cairns, J. (2000). Negative and zero time preferences for health. Health Econ 9, 171-175.

Van der Pol, M., \& Cairns, J. (2001). Estimating time preferences for health using discrete choice experiments. Soc Sci Med 52, 1459-1470.

Vul, E.., Harris, C., Winkielman, P., \& Pashler, H. (2009). Puzzlingly high correlations in fMRI 16 studies of emotion, personality, and social cognition. Perspect Psychol Sci, 4(3).

Winstanley, C. A., Theobald, D. E., Cardinal, R. N., \& Robbins, T. W. (2004). Contrasting roles 17 of basolateral amygdala and orbitofrontal cortex in impulsive choice. J Neurosci 24 , 4718-4722.

Yoshida, W., \& Ishii, S. (2006). Resolution of uncertainty in prefrontal cortex. Neuron 50, 781-789.

Young, P. T. (1959). The role of affective processes in learning and motivation. Psychol Rev $66,104-125$. 